\title{
Ecological Study Coastal Management of Tanjung Tiram Village Konawe Selatan
}

\author{
Ferasari Ferasari ${ }^{1}$, La Sara ${ }^{2}$, La Rianda ${ }^{3}$, Onu La Ola ${ }^{4}$ \\ \{ferasari419@yahoo.com ${ }^{1}$, lasara_unhalu@yahoo.com ${ }^{2}$, \\ rianda.baka@gmail.com ${ }^{3}$,onu.laola@yahoo.com ${ }^{4}$ \} \\ ${ }^{1}$ Postgraduate Program at Halu Oleo University Agricultural Sciences Kendari 93118 \\ Southeast Sulawesi, Indonesia \\ ${ }^{2}$ Study Program of Marine Resources Utilization, Faculty of Fisheries and Marine \\ Sciences, Halu Oleo University Kendari 93232, Southeast Sulawesi, Indonesia \\ ${ }^{3}$ Study Program of Food Technology, Faculty of Agricultural Technology and Industry \\ Halu Oleo University Kendari 93232, Southeast Sulawesi, Indonesia \\ ${ }^{4}$ Study Program of Agribusiness, Faculty of Fisheries and Marine Sciences, Halu Oleo \\ University Kendari 93232, Southeast Sulawesi, Indonesia
}

\begin{abstract}
The study aims to determine the ecological coastal management of Tanjung Tiram village. The research method carried out is a biophysical ecological measurement of Mangrove, Seagrass and Coral ecosystems. The variable measured is the extent of coral cover, with the LIT measurement method at two points of the measurement station. Analysis and identification are based on the form of growth (life-form) with identification codes referring to English et al. (1997) and Veron (2000) [10]. In the Seagrass Ecosystem, measurements are made through the quadratic transect method stretched perpendicular to the coastline, to determine species composition and the percentage of seagrass cover (English et al, 1994), making $10 \mathrm{~m}$ x $10 \mathrm{~m}$ observation plots randomly placed. The results showed that the two stations observed in the coral reef ecosystem were categorized as very good $(75-100 \%)$, in the mangrove ecosystem under moderate ecological pressure with a diversity index of 0.92 and 2.60. In Seagrass ecosystems, seagrass cover at stations 1 and 2 varies from $2 \%$ to $40 \%$.
\end{abstract}

Keywords: Coastal management, Ecology, Tanjung Tiram

\section{Introduction}

Coastal areas are a potential resource in Indonesia with a coastline of $81,000 \mathrm{~km}$ (Dahuri et al. 2001). This long coastline saves the potential of the rich natural resources of fisheries, mangrove forests, and coral reefs, minerals and minerals and tourism. The coastal conditions in Indonesia are very varied, starting from the white-rocky, steep-sloping, vegetation-muddy, shady, undulating beaches that all are very suitable for various purposes, such as coastal fisheries, aquaculture, the hospitality industry, tourism, and others-other.

\section{Research methods}

The research was conducted in October 2016 until June 2018. Ecological and biophysical measurements were carried out on the mangrove, seagrass and coral ecosystems in the waters of Tanjung Tiram village, North Moramo District, South Konawe Regency. The variable 
measured is the extent of coral cover using measurements of Line Intercept Transect at two points of the measurement station. Taking biophysical data on coral reefs is done by diving (Scuba Dive). Analysis and identification of basic habitat filler biota based on the form of growth (life-form) with identification code refers to English et al. (1997) and Veron (2000) [10]. In the Seagrass Ecosystem, measurements of seagrass community structures are carried out through the quadratic transect method stretched perpendicular to the shoreline. This method is used to determine species composition and the percentage of seagrass closure (English et al, 1994). Technically, measurements are made by making observation plots covering an area of $10 \mathrm{~m} \times 10 \mathrm{~m}$. In the plot, a square size of $1 / 2 \mathrm{~m} \times 1 / 2 \mathrm{~m}$ is placed in parallel to the area of observation. Mangrove ecosystems, collected mangrove data include species, species composition, species density, type frequency. Mangrove measurements in the field were carried out using 10 x 10 meter plots / plots randomly placed.

\section{Results}

Based on the results of the measurement of species composition at station 1 the dominance of the species Rhizopora sp with a percentage of $71.01 \%$ Sonneratia sp $28.99 \%$, at station 2 is dominated by the type Rhizopora sp with a percentage of $73,08 \%$, Sonneratia sp $25 \%$, Cylocarpus sp 1, 92\% and at station 3 Rhizopora sp 54\%, Sonneratia sp 36\%, Bruguiera sp $10 \%$. Thus, for all stations 1,2 and 3 the composition of species is dominated by the type of Rhizopora sp with a percentage of $66 \%$, Sonneratia sp 30\%, Cylocarpus sp 3\%, and Bruguiera sp $1 \%$. This is consistent with Dahri (1996), that several types of mangrove trees commonly found in the Indonesian coastal areas are mangroves (Rhizophora spp), Apiapi (Avicennia spp), Pedada (Sonneratia spp), Tanjang (Bruguiera spp), Nyirih (Xylocarpus spp) ), Tengar (Ceriops spp) and Blind-blind (Exoacaria spp).

Physical measurement of seagrass ecosystems at station 1, frequency of seagrass species is highest in the type of Thalassia hemprichi with a frequency of occurrence as much as 20 times while the lowest in the type of universal Holodule with a frequency of occurrence of 1 time. Frequency of Relative Closure of Seagrass Types at station 1, the highest in the type of Thalassia hemprichi by $40 \%$ while the lowest in the type of Holodule pinifolia by $2 \%$. The frequency of seagrass species at station 1 was highest in the type of Thalassia hemprichi which was 0.4 while the lowest in the type of universal Holudule was 0.02 .

Measurement of Coral Reef conditions in Tanjung Tiram Village waters station 1 with coordinate points 40251.61 LS 12204019.13 BT dominated by Acropora Brangching (ACB) type with a percentage of coral cover of 55.6\%, type Dead Coral With Algae (DCA) 22,8\%, Type Fleshy Seaweed (FS) 7.1\%, Coral Foliose (CF) 6.58\%, Coral Mushroom (CM) 4.24\%, Dead Coral (DC) 1.7\%, Coral Summasive (CS) 1.38\%, Type Soft Coral (SC) 0.7\%, Type Other (OT) $0.64 \%$, Rubble Type (R) $0.42 \%$. Whereas at station 2 facing 100 meters perpendicular to the location of the $2 \times 50$ MW PLTU jetty, dominated by the type of Acrophora Branching (ACB) 37.36\%, type Dead Coral With Algae(DCA) 16.74\%, Coral Type Submasive (CS) $10.76 \%$, Silt Type 8.36\%, Type Dead Coral (DC) $6.66 \%$, Tabulate (ACT) Acropora type $2.72 \%$, Massive Coral (CM) type $2.46 \%$, Coral Foliose type (CF) 2, 46\%, Coral Encrusting (CE) 2.36\%, Rock (RK) 1.88\%, Coral Mushroom (CMR) $1.54 \%$, Soft Coral (SC) $1.34 \%$, type of Acropora Encrusting (ACE) $1.02 \%$, type Sand (S) $0.9 \%$, type Coral Branching (CB) 0,74\%, type Rubble (R) 0.56\%, type Acropora Digitate (ACD) 0 , 38\%, type Other (OT) $0.28 \%$. 


\section{Discussion}

Based on the measurement results at stations 1 and 2, the lowest or densest level of mangrove density is found at station 2 with an average density of $1 \mathrm{~m} 2$ or 1000 trees (ha). The density of mangrove vegetation is very closely related to the existence of a relatively protected estuary that has a periodic supply of fresh water with the muddy base type of water which is very supportive of mangrove growth.

The high density of mangrove vegetation is very closely related to the existence of a relatively protected estuary, there is a periodic supply of fresh water with a muddy base type of water that strongly supports mangrove growth.

Mangrove conditions can be seen from the diversity index benchmark value $\left(\mathrm{H}^{\prime}\right)$ as follows:

1. If $H^{\prime}<1.0$, then the condition of mangroves has low diversity, is poor (very low productivity) as an indication of heavy ecological pressure, and an unstable ecosystem.

2. If $1.0<3.222$, then the condition of mangroves has moderate diversity, sufficient productivity, balanced ecosystem conditions, and moderate ecological pressure.

3. $\mathrm{H}^{\prime}>3.222$, the mangrove condition has high diversity, stable ecosystem stability, and high productivity.

With the $\mathrm{H}$ value indicator, the value of the mangrove ecosystem around the village of Tanjung Tiram is under moderate ecological pressure with a diversity index of 0.92 and 2.6 (Data Primary, 2017).

Mangrove ecosystems have very important ecological functions, in addition to providing goods and services. This ecosystem functions as a trap for sediments, so it can prevent erosion and coastal abrasion (Ewel, et., Al 1998 [7]; Mazda, 2002 [9]). The nutrient cycle that occurs in it plays a role in providing sources of nitrogen and phosphorus for all tropical levels in mangrove forest ecosystems and surrounding ecosystems (seagrass and coral), and improving water quality (Ewel et al, 1998) [7]. Through the carbon cycle, mangrove forest ecosystems function in regulating the accumulation of carbon dioxide in the atmosphere, both as a source and store of carbon (Chumura et. Al 2003 [3]; Alongi, 2008 [1]).

Seagrass cover at stations 1 and 2 varies from $2 \%$ to $40 \%$ for station 1 while for station 2 , seagrass cover starts from $2 \%$ to $74 \%$, so that for stations 1 and 2 , seagrass cover is categorized as damaged and there are those that are still good. This is based on the Decree of the Minister of Environment No. 200 of 2004 concerning Damage Standard Criteria and Guidelines for Determining Seagrass Status, status criteria in seagrasses as the table below:

Table 1. Standard Criteria for Damage and Termination of Seagrass Status

\begin{tabular}{|lr}
\hline Closing Conditions & $(\%)$ \\
Well & $>=60 \%$ \\
Rich / Healthy & $30-59,9$ \\
Damaged less rich / less healthy & $<=29.9$ \\
Poor & $<$
\end{tabular}

Seagrass beds are very productive ecosystems. Each year it can produce around 45.7 tons equivalent of dry organic matter per Ha (Den Hartog, 1977) [5]. Ecologically, seagrass beds have an important function for coastal areas, namely: 1). As a primary producer; 2) stabilizing the watershed with its dense root system and crossing each other; 3) a place to find food and protect from predators like various organisms; 4) as a silencer so that it becomes calmer 
waters; and 5) as a protective covering from the sun's heat for its inhabitants (Nybakken, 1988 ; Schubel, 1977; Peres, 1977; Mukai, 1991).

Nontji (2010) outlines four main types of causes of damage to seagrass ecosystems originating from human activities, namely: 1) physical damage, 2) pollution, 3) use of nonenvironmentally friendly fishing gear and 4) overfishing, namely resource exploitation which exceeds the ability to recover.

Seagrass ecosystems provide a variety of environmental products and services to the surrounding ecosystems, such as mangroves and coral reefs, as well as people living in the vicinity (Cullen-Unsworth et al. 2013) [4]. The results of the Torre-Castro and Ronnback (2004) study of the relationship between seagrass and humans in east Africa show that seagrasses provide environmental services as fishing grounds, places for fish traps, sources of biota for the community and provide land for seaweed farming. The group of fish caught in seagrass ecosystems generally comes from the Scaridae family, Siganidae, Mullidae Labridae and Lethrinidae.

In the context of seagrass ecosystem services, it can be interpreted as the benefits that can be taken from the ecosystem by the people who live around it. This was revealed by ToreCastro and Ronnback (2004) in Chiwaka village, East coast of Zanzibar. They also said that the economy of rural communities in coastal areas has a large dependence on marine resources as a source of food and income. Therefore an investigation of ecosystem functions and services is very necessary to know the framework for managing an ecosystem (Adrianto 2009; Costanza 2007), including management of seagrass ecosystems. The management of seagrass ecosystems is certainly inseparable from the theories of coastal and marine management planning. Kay and Alder (1999) say that coastal management planning approaches tend to be part or a combination of a number of planning theories to provide the best planning solutions, namely rational, incremental, adaptive and consensual planning. Sustainable development is the end of management objectives which have accommodated ecological, social, and economic aspects that are in an interrelated and integrated state (Chua, 2006). In the Coral Reef Ecosystem, based on the Minister's decision on the State of the Environment No. 4 of 2001 About: Criteria for Coral Reef Damage Standards (in\%) are: About: Criteria for Coral Reef Damage Standards (in $\%$ ) are:

$\begin{array}{ll}\text { - Bad } & : 0-24.9 \\ \text { - Moderate } & : 25-49,9 \\ \text { - Good } & : 50-74,9 \\ \text { - Very good } & : 75-100\end{array}$

Overall, from the two stations of the Coral Reef Ecosystem that are observed, they are categorized as good, so they need to be preserved. This is in accordance with the opinion (Nybakken,1988; 1993). High productivity occurs thanks to the presence of microalgae or Zooxanthella which symbiosis with coral polyps and other coral animals. It is this production that sustains a very diverse and specialized life in the area of coral reefs. Whereas according to Mardianto, et al (2015), Tanjung Tiram waters have a percentage of live coral cover in Tanjung Oyster waters, namely $61.15 \%$. The condition of the quality of Tanjung Oyster waters is $280 \mathrm{C}$, salinity is $34 \mathrm{ppt}$,current velocity is $0.07-0.20, \mathrm{pH} 7$ and brightness is $100 \%$ (Mardianto et al. 2015).

According to Bengen (2002) that environmental physical factors that play a role in the development of coral reefs are 1). Water temperature plays an important role for coral growth and development. Whereas according to Wells (1957) in Ramli (2003), coral reefs do not 
develop at annual minimum temperatures below $180 \mathrm{C}$, and most optimally occur in the average annual water temperature below 250C-290C. According to Kinsman (1964) in Suproharyono (2007) that the minimum and maximum temperatures range between 160C$17^{\circ} \mathrm{C}$ and around $36^{\circ} \mathrm{C}$. This is what causes many coral reefs to be found in large areas in tropical waters. However tolerance of constituents to changes in temperature differs between one species and another species.

Overall, the coastal area of Tanjung Tiram Village has waters whose Bio-physical parameter values are in the form of temperatures ranging from $30 \mathrm{oC}$, salinity ranging from $26-$ $30 \mathrm{o} / \mathrm{oo}$, water depths ranging from 3 to $7 \mathrm{~m}$, dissolved oxygen ranging from 6.2 to $7.2 \mathrm{ppm}$, waves range from $10-13 \mathrm{~cm}$, protection: open, with the base of the sand and sandy substrate waters, current velocity ranges from $4.6-5 \mathrm{~cm} / \mathrm{sec}$, brightness $80-100 \%$, phosphate ranges from $0.0170 \mathrm{mg} / 1-0,0190 \mathrm{mg} / 1$, and nitrates range from $0.007-0.0082 \mathrm{mg} / 1$. Under these conditions, each parameter in each region shows normal conditions that can still support the life of aquatic organisms, especially capture fisheries, marine aquaculture and brackish activities.

According to Alder (1997), the involvement of the local management system and community involvement or institutionalizing existing ways of local management are incorporated into the coastal area management system starting from the initial planning, such as formulating community desires, determining management, implementation, monitoring and evaluation. The involvement of the local management system and the involvement of the community in managing the coast have several significant benefits, including: a). Can accommodate the interests of the community, especially local people who are most affected first in the implementation of coastal management; b) Can help identify existing problems more precisely, even more accurately when compared with problem identification formulations prepared by planning experts; c) Reducing the level of opposition to management implementation. With community involvement, planning information is more transparent and the community has information accessibility to management plans so that the community can be involved in management.

\section{Conclusion}

Based on the biophysical measurements of three ecosystems, the Coral Reef Ecosystem, Mangrove Ecosystem and Seagrass Ecosystem are still in good category so it needs to be considered a coastal management that pays attention to ecological conditions so that the sustainability of these three ecosystems is maintained.

\section{Acknowledgments}

To the team of researchers who have collaborated as long as this research was carried out to completion, Director of the Graduate School of the Haluoleo University and the Kerua Agricultural Study Program of the Halu Oleo University Doctoral, Post-graduate Program. To families who always provide support in completing my studies. 


\section{References}

[1] Alongi D.M., 2012. Carbon Sequestration in Mangrove Forests. Carbon Management. 3: 313-322.

[2] Burrell, D.C. \& Schubel, J.R. 1977. Seagrass ecosystem oceanography. in: McRoy, P and Mc Millan, C. (eds). Seagrass Ecosystem: a Scientific Perspective. New York: Marcel Dekker.

[3] Chmura G.1., Anisfeld S.C., Cahoon D.R., \& Lynch J.C., 2003. Global Carbon Sequestration in Tidal, Saline Wetland Soils. Global Biogeochemical Cycles, 17.

[4] Cullen-Unsworth L and Unsworth R. 2013. Seagrass Meadows, Ecosystem services and Sustainability. Environment, 53 (3): 14-28

[5] Den Hartog, C. 1977. Seagrass and Seagrass Ecosystem, An Appraisal of The Research Approach, Aquat. Bot. 105-177.

[6] English, S., C. Wilkinson and V. Baker (ed.). 1994. Manual for tropical marine survey research. ASEAN-Australia marine science project. Australian Institute of Marine Science. Townsville. 390p. Erftemeijer, P. L.A., B. Riegl, B.W. Hoeksema and P.A. Todd. 2012. Environmental impacts of dredging and other sediment disturbances on corals: a review. Marine Pollution Bulletin, 64: 1737-1765.

[7] Ewel, K.C., R.R. Twilley, and J.E. Ong. 1998. Different types of mangrove forests provide different goods and services. Global Ecology and Biogeography Letters 7 (1): 83 - 94. FAO. 1994. Mangroves Forest Management Guidelines. Forestry Paper No. 117, Rome.

[8] KIKUCHI, T and J.M. PERES 1977. Consumerecology of seagrass beds. In: Seagrassecosystem; a scientific perspective.Marcel Dekker, Inc. New York. 147-194.

[9] Mazda, Y., M.Magi, H.Nanao, M.Kogo, T.Miyagi, N.Kanazawa, and D.Kobashi. 2002. Coastal corrosion due to long-term human impact on mangrove forests. Wetlands Ecology and Management 10: 1 - 9.

[10] Veron, J.E.N. 2000a. Corals of the world.Vol 1.Australian Institute of Marine Scinces, Townsville. 463p.Veron, J.E.N. 2000b. Corals of the world.Vol 2. Australian Institute of Marine Scinces, Townsville. 429 p. 